\title{
The Influence of Colour Trap to The Community Structure on Apple Plant in Junggo, Tulungrejo Village, Bumiaji District, Batu City (Preliminary Study about Armoured Scale (Diaspididae family))
}

\author{
Sama' Iradat Tito ${ }^{1}$, Gatot Mudjiono ${ }^{2}$, Abdul Latief Abadi ${ }^{2}$, Toto Himawan ${ }^{2}$ \\ ${ }^{1}$ Post Graduate, Faculty of Agriculture, Brawijaya University, Malang \\ ${ }^{2}$ Department of Pest and plant diseases, Faculty of Agriculture, Brawijaya University, Malang
}

\begin{abstract}
Scales have attacked 9 hectares of apple land spread in 8 villages of Bumiaji sub-district such as Giripurno village, Tulungrejo village, Pandanrejo village, Sumbergondo village, Bulukerto village, Punten village, Gunungsari village, and Bumiaji village. This pest is a perennial pest on apple crops and difficult to control. The current way of control has not been able to overcome this pest problem. Therefore, research is needed to get effective control technology and easy to implement. The use of colour traps in addition to control needs, and also expected to needs of monitoring and identification of existing problems that make this pest difficult to control. This research was conducted to find out the effect of colour trap to community structure at Junggo, Tulungrejo Village, Bumiaji Sub-district, Batu City. Colour traps are fitted with 10 types of treatment colour with 3 replication. The observational data were analyzed by using community test. The results showed that the community analysis on the colour trap indicating that the index of diversity $\left(\mathrm{H}^{\prime}\right)$ and the dominance index $(\mathrm{C})$ all treatments and families were small but the uniformity index $(\mathrm{E})$ belonged to the stable community was owned by treatment B8 white colour with height $1.5 \mathrm{~m}$ ) and B9 (clear colour with height $1 \mathrm{~m}$ ). The largest dominant index (C) data of Diaspididae family (scales) is owned by B7 treatment (white colour with height $1 \mathrm{~m}$ ) of 0.18 . The natural enemy species of scales found on apple plants is Encarsia strenua (silvestri): Famili Aphelinidae.
\end{abstract}

Keywords: Apple, Colour trap, Scales

\section{INTRODUCTION}

Apple plants are horticultural commodities that quite important, because it has a high economic value. Apple production in East Java is Batu City and District Poncokusumo Malang Regency. Increased production of apple crops has made the city of Batu as a center of East Java apple crop. Agro-climate conditions that are generally dry highland is very suitable for apple farming business. Apple plants have tolerance to the height of the place make the identity of Batu City (13).

Batu Town is an apple producing center in Indonesia which has an apple land area of 2,993.89 Ha which is centered in Bumiaji District. Tulungrejo village in Bumiaji district is at an altitude of 700-800 meters above sea level (mdpl) (5). Apples area in Tulungrejo village is $400 \mathrm{Ha}$ with total production of apple 11.000 ton per harvest season with productivity 27.5 ton / Ha / year (6).

\footnotetext{
Correspondence address:

Sama' Iradat Tito

Email : tito_bio_04@yahoo.co.id

Address : Post Graduate, Faculty of Agriculture, Brawijaya University, Malang
}

Based on information that has been circulating that the scales have attacked 9 hectares of apple land spread in 8 villages Bumiaji District such as Giripurno village, Tulungrejo village, Pandanrejo village, Sumbergondo village, Bulukerto village, Punten village, Gunungsari village and Bumiaji village (11).

Traps can be used with attractant, visual pullers (colour, light, shape), chemicals (food / host, pheromone, oviposition) and acoustic stimuli. Insect traps are an important part of control even though trap-type systems and frameworks are often discussed and debated (9).

According to (4), insects have a special sensor system, so insects can find and receive host appropriate for feeding and breeding activities. This sensor system is able to assimilate olfactory (olfactory), visual (visual), and mechanical stimulation to accept or reject the host. The olfactory sensor system moves the insects to find the source of the smell (aroma). While the vision system is used to locate the host, then the insects rest on the host surface. In a natural environment, herbivorous insects are exposed to many stimuli. The use of two main sensor systems, both olfaction and vision, strengthens 
the ability of insects to locate hosts. Based on this, will be tried the colour trap to the community structure in Pedukuan Junggo, Tulungrejo Village, Bumiaji Sub-District, Batu City.

\section{MATERIAL AND METHODE METHODS}

Visual traps aim to get insects attracted by colour. This research was conducted factorially by using Completely Randomized Design (RAL) which consist of 2 factors:

Factor 1 is Repetition

$\mathrm{U} 1$ is the first Repeat

$\mathrm{U} 2$ is the second Repetition

$\mathrm{U} 3$ is the third repetition

Factor 2 is a Colour Trap with 10 kinds

B1: Square Green colour with Trapping height of $1 \mathrm{~m}$

B2: Square Green colour with $1.5 \mathrm{~m}$ trap mounting height

B3: Square Blue colour with Altitude mounting trap $1 \mathrm{~m}$

B4: Square Blue colour with $1.5 \mathrm{~m}$ trap mounting height

B5: Square Yellow colour with Trapping height of $1 \mathrm{~m}$

B6: Square Yellow colour with $1.5 \mathrm{~m}$ trap mounting height

B7: Square White colour with Trapping height of $1 \mathrm{~m}$

B8: Square White colour with $1.5 \mathrm{~m}$ trap mount height

B9: Square of clear colour with Trapping height of $1 \mathrm{~m}$

B10: Square clear colour with $1.5 \mathrm{~m}$ trap mounting height

The combination of these two factors produced 30 experimental units.

Table 1. Visual Trap Treatment of Scales

\begin{tabular}{|c|c|c|c|}
\hline \multirow[b]{2}{*}{$\begin{array}{l}\text { Treatment } \\
\text { Colour trap }\end{array}$} & \multicolumn{3}{|c|}{ Repetition } \\
\hline & U1 & U2 & U3 \\
\hline B1 & B1U1 & B1U2 & B1U3 \\
\hline B2 & B2U1 & B2U2 & B2U3 \\
\hline B3 & B3U1 & B3U2 & B3U3 \\
\hline B4 & B4U1 & B4U2 & B4U3 \\
\hline B5 & B5U1 & B5U2 & B5U3 \\
\hline B6 & B6U1 & B6U2 & B6U3 \\
\hline B7 & B7U1 & B7U2 & B7U3 \\
\hline B8 & B8U1 & B8U2 & B8U3 \\
\hline B9 & B9U1 & B9U2 & B9U3 \\
\hline B10 & B10U1 & B10U2 & B10U3 \\
\hline
\end{tabular}

The visual trap is a coloured board measuring 10 $\mathrm{cm} \times 10 \mathrm{~cm}$ with a double-sided coated square and hung with a wire on a branch of a plant that has been estimated to be affected by pests of ticks and adapted to a variation of research height of $1 \mathrm{~m}$ and $1.5 \mathrm{~m}$. The data obtained is tabulated and calculated the average of the population on apple crops with the formula:

$$
\mu=\frac{\sum x i}{n}
$$

Description: $\mu$ is the average population per type of insect

$x i$ is the number of insects found per type of insect

$\mathrm{n}$ is the number of replications

\section{Data Collection}

At each observation in the field will be installed 30 visual traps and trap taking will be done 3 days after installation. The visual trap mounting interval will be held every 2 weeks. It aims to allow time for the identification and naturalization of the field (return of the environment under normal conditions). The identification of insects is by using the following guidebook: (1) Identification of scales using Arthropods of economic importance: Diaspididade of the world, (2) Identification of natural enemies using a pocket guide to the common natural enemies of crop and garden pests in the pasific northwest, and Identification of apple plant insects using Deciduous fruit and nut trees and olive. Observed with a light microscope on a red ribbon (4x magnification) and with a yellow ribbon (10x magnification).

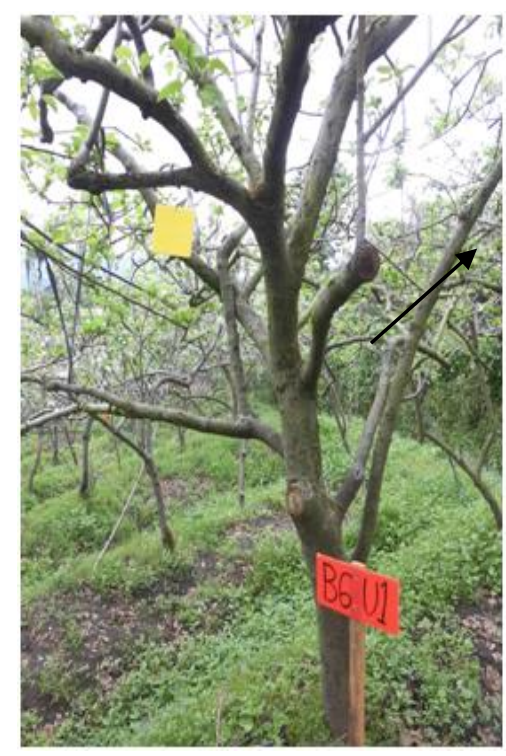

Figure 1. Visual trap 


\section{Data Analysis Research}

The analysis used is the analysis of community structure and diversity analysis. The community structure is analyzed using an important value index to determine the size of a family's role. The Important Value Index (INP) is the sum of the relative abundance value $(K R)$ and Relative Frequency (FR). Diversity was calculated using the Shannon Wiener index. On sampling using visual traps, the abundance of scales is compared per month. Analysis of variance is used to compare the mean abundance of insects under certain environmental conditions.

The analysis of community structure is determined by the diversity index $\left(\mathrm{H}^{\prime}\right)$, diversity index (E), and dominance index. The following indices of each community index are used: The diversity or diversity index ( $H^{\prime}$ ') states the condition of the population of the organism mathematically in order to facilitate in analyzing the information of the number of individuals within a community (10). The most commonly used diversity index is the Shannon-Weaner index $(10 ; 7)$ by the formula:

$$
\mathrm{H}^{\prime}=\sum_{i-1}^{S} P i \ln P i
$$

Uniformity index Where $\mathrm{H}^{\prime}=$ Index of diversity; $\mathrm{Pi}$ = Comparison of $\mathrm{i}$ proportion; $\mathrm{S}=$ Number of species found. Natural logarithms (In) are usually used for certain communities that have relatively high abundance and preferences of specific habitats. It can also be used Log2. Because Log2 or 2 Log or logarithm with the base number 2 of a numerical expression can be expressed as $2 \log x$, then $2 \log x$ can be declared to be $(\log x / \log 2)=$ $3.32 \log x$. The thing to watch out for is to be consistent in using Ln or Log. The Diversity Index (E) The uniformity or equitability index (E) represents the spread of individuals between different species and is derived from the relationship between diversity $\left(H^{\prime}\right)$ and its maximum diversity. The more evenly distributed individuals between species then the balance of the ecosystem will increase. The formula used is (10):

$$
\mathrm{E}=\frac{H^{\prime}}{H \max }
$$

Where $\mathrm{E}=$ uniformity index; $\mathrm{H} \max =\mathrm{Ln} \mathrm{S}$; and $\mathrm{S}$ $=$ Number of reef fish found. The uniform index value ranges from 0 to 1 . Furthermore, the uniform index value based on (7) is categorized as follows: $0<\mathrm{E} \leq 0.5$ : Community depressed; 0.5
$<\mathrm{E} \leq 0.75$ : Community unstable; $0.75<\mathrm{E} \leq 1$ : The community is stable. The smaller the index of uniformity, the smaller the uniformity of the population, it shows the spread of the number of individuals of each species is not the same so there is a tendency of one type of biota dominate. The greater the value of uniformity, describing the number of biota in each type is the same or not much different. Dominant Index (C) The dominant index based on the number of individual species is used to see the dominant level of certain biota groups. The equation used is the dominance index (10), ie:

$$
\mathrm{C}=\sum_{i-1}^{S}(P i)^{2}
$$

Where $\mathrm{C}=$ Index of dominance; $\mathrm{Pi}=$ Comparison of proportion of fish to $\mathrm{i} ; \mathrm{S}=$ Number of species found. The value of dominance index ranges from 1 - 0 . The higher the index value, it will be seen that a biota dominates the bottom substrate of the waters. If the value of the dominance index (C) is close to zero, then this indicates that there is no dominant biota and is usually followed by a high uniformity (E) value. Conversely, if the value of the dominance index (C) is close to one, then it illustrates that in the waters there is one dominant biota and is usually followed by a low uniformity value. The dominant index values are grouped into 3 criteria, namely: $0<\mathrm{C} \leq 0.5$ : Low dominance; 0.5 $<C \leq 0.75$ : Moderate dominance; $0.75<\mathrm{C} \leq 1$ : High dominance.

\section{RESULTS AND DISCUSSION}

Colour can be defined as part of vision sensing, or as the nature of the transmitted light. The process of visible colour is due to the light that hit an object and the object is reflected light to the eye (retina) so that the colour can be seen.

Scales are hemimetabola insects. The hemimetabola insect is complemented by three single eyes (ocelli), in addition to compound eyes. The single eye has nothing to do with the function as a visual device but is very sensitive to light of very low intensity. Insects are also able to capture direct light through the brain cells (12). The single eye has a single lens that serves to distinguish colours. These two eyes work together towards the stimuli of certain colours (2). 
Table 1. Dominance and Uniformity Index of Diaspididae Families Trapped in Various Color Traps

\begin{tabular}{lcc}
\hline \multicolumn{1}{c}{ Type of Color Trap with Altitude } & C & E \\
\hline Square Green Height 1,0 m & 0,06 & 0,60 \\
Square Green Height 1,5 m & 0,04 & 0,71 \\
Square Blue Height 1,0 m & 0,02 & 0,73 \\
Square Blue Height 1,5 m & 0,05 & 0,54 \\
Square Yellow Height 1,0 m & 0,01 & 0,62 \\
Square Yellow Height 1,5 m & 0,01 & 0,59 \\
Square White Height 1,0 m & 0,18 & 0,61 \\
Square White Height 1,5 m & 0,04 & 0,77 \\
Square Clear Height 1,0 m & 0,00 & 0,85 \\
Square Clear Height 1,5 m & 0,05 & 0,63 \\
\hline
\end{tabular}

Remarks: $\mathrm{C}$ is dominance index; and $\mathrm{E}$ is the uniformity index

Table 2. Dominance and Uniformity Index of Aphelinidae Families Trapped in Various Color Traps

\begin{tabular}{lcc}
\hline \multicolumn{1}{c}{ Type of Color Trap with Altitude } & C & E \\
\hline Square Green Height 1,0 m & 0,00 & 0,60 \\
Square Green Height 1,5 m & 0,00 & 0,71 \\
Square Blue Height 1,0 m & 0,01 & 0,73 \\
Square Blue Height 1,5 m & 0,00 & 0,54 \\
Square Yellow Height 1,0 m & 0,00 & 0,62 \\
Square Yellow Height 1,5 m & 0,00 & 0,59 \\
Square White Height 1,0 m & 0,00 & 0,61 \\
Square White Height 1,5 m & 0,01 & 0,77 \\
Square Clear Height 1,0 m & 0,00 & 0,85 \\
Square Clear Height 1,5 m & 0,00 & 0,63 \\
\hline
\end{tabular}

Remarks: $\mathrm{C}$ is dominance index; and $\mathrm{E}$ is the uniformity index

The results of community analysis calculations on colour traps indicate that the diversity index $\left(\mathrm{H}^{\prime}\right)$ and the dominance index (C) of all treatments and families are small but the uniformity index (E) belongs to a stable community owned by B8 treatment (white with a height of $1.5 \mathrm{~m}$ ) and $\mathrm{B} 9$ (clear colour with height $1 \mathrm{~m})$. This indicates the number of biota caught in the trap is the same or not so different that no one dominates. For other treatments the diversity index (E) obtained is categorized as a volatile community which can mean that the community is found among the depressed and stable. The largest dominant index (C) data of the Diaspididae family (scales) is owned by the B7 treatment (white colour with height $1 \mathrm{~m}$ ) of 0.18 .

The highest yield of dominance is obtained from white traps with a height of $1 \mathrm{~m}$ because white objects are assumed to be like sunlight (ultraviolet) which is actually a combination of various colors so that it will be more easily accepted by the receiving object. The highest response to insects is light near ultraviolet (350 $\mathrm{m} \mu$ ) (12). This is supported by the opinion of (8), one type of insect vision pigment, a pigment that can absorb ultraviolet light. Insects are attracted to the wavelength of light that approaches ultraviolet light, because it already has a perfect shadow formation mechanism. The light receptors in these insects are in the form of a pair of compound eyes and 3 ocelli (single eyes).

The natural enemy species of scales found on apple plants is Encarsia strenua (silvestri): Famili Aphelinidae. This is reinforced by Heraty (2007), that $E$. strenua has spread on the Indonesian island of Java. Encarsia on observation is more often found in traps B3 (Square Blue Height 1,0 m) dan B8 (Square White Height $1,5 \mathrm{~m}$ ). This is according to the opinion (8) and (1), that most insects have only two types of vision pigments, that is, pigments that can absorb blue and ultraviolet light. 


\section{CONCLUSIONS}

Community analysis on colour traps indicating that the index of diversity $(\mathrm{H}$ ') and the dominance index (C) all treatments and families were small but the uniformity index (E) belonged to a stable community owned by B8 treatment (white with height $1.5 \mathrm{~m}$ ) and $\mathrm{B9}$ (clear colour with height $1 \mathrm{~m}$ ). The largest dominant index (C) data of Diaspididae family (scales) is owned by B7 treatment (white colour with height $1 \mathrm{~m}$ ) of 0.18 . The natural enemy species of scales found on apple plants is Encarsia strenua (silvestri) : Famili Aphelinidae.

\section{ACKNOWLEDGMENTS}

The authors would like to say thank you very much to Prof. Dr. Ir. Soemarno as the Director of Postgraduate Agriculture Universitas Brawijaya and Mr. Amin Setyo Leksono Ph.D as Reviewer.

\section{REFERENCES}

[1].Bes \& Haromoto, 1961. Contribution To The Biology and Ecology Of The Oriental Fruit Fly Dacus Dorsalis. University Of Hawaii. Honolulu.

[2].Borror, D.J .; Triplehorn, C.A .; and Johnson, N. F. 1996. Introduction to the Sixth Edition of Insect Study. Gadjah Mada University Press. Yogyakarta.

[3]. Campbell. 1999. Biology volume I. Edition V. Erland. Jakarta.

[4].Doles, J. L. 2001. Host Plant Selection and Acceptance Behavior of Herbivorous insects (phytophagus insects). Available on line at http; www.colostate.edu/Depts/Entomolgy/course s/euso7/papers2001/doles.htm Accessed on 15 November 2018 At 19.00 WIB
[5].Fahriyah, Heru S., and Sherley S. 2011. Impacts of Climate Change on Production and Revenue of Apple Farmers (Malus sylvestris). Agrise XI, (3): 189-194.

[6].Indahwati, R. Budi H., and Munifatul I. 2012. Arthropod Diversity of Soil in Tulungrejo Village Tulungrejo Subdistrict, Batu Bumiaji Sub-District. Paper presented at the National Seminar on Natural Resources and Environment Management, Diponegoro University, Semarang, September 11, 2012.

[7].Krebs, C.J. 1999. Ecology Methodology Second Edition. Addision Wesley Longman Inc. California.

[8].Meyer, R.J. 2006. Colour Vision. Department of Entomology NC State University. Available online at: http://www.cornell.go.id Accessed March 21, 2018.

[9].Nancy D. Epsky, Wendell L. Morrill, Richard W. Mankin. 2008. Traps for Capturing Insects. In Capinera, John L. (Ed.). Encyclopedia of Entomology (PDF). Dordrecht: Springer. Pp. 3887-3901. ISBN 1402062427.

[10]. Odum, E.P. 1971. Foundamental of Ecology. Saunders and Toppan. Tokyo. Japan.

[11]. Scales Attack 9 Hectares Apple Garden. Radar Batu Jawa Pos Saturday 20 August 2015 pp. 37-38

[12].Sodiq, M. 2009. Plant Resistance Against Pests. Faculty of Agriculture. National Development University "Veterans". East Java.

[13].Sunarjono, H. 2013. Gardening 26 Types of Fruit Plants. Jakarta. The Swadaya spreader. p. 156-160.

\section{ATTACHMENT}

COMPOSITION OF INSECTS IN THE COMMUNITY CAPTURE

Composition Community of apple plant bugs caught trap of B1 colour (green colour 1m height) 


\begin{tabular}{c|c|c|c|c|c|c|c|r|r|r|r|} 
No & Family & $\mathrm{D}$ & $\mathrm{DR}$ & $\mathrm{F}$ & $\mathrm{FR}$ & $\mathrm{V}$ & $\mathrm{pi}$ & $\mathrm{In}(\mathrm{pi})$ & \multicolumn{1}{|c|}{$\mathrm{H}^{\prime}$} & $\mathrm{C}$ & $\mathrm{E}$ \\
\hline 1 & Cecidomyiidae & 1 & 4,76 & 9 & 12,33 & 17,09 & 0,05 & 3,04 & 0,14 & 0,00 & \\
\hline 2 & Drosophilidae & 0 & 0,00 & 2 & 2,74 & 2,74 & 0,00 & 0,00 & 0,00 & 0,00 & \\
\hline 3 & Braconidae & 6 & 28,57 & 10 & 13,70 & 42,27 & 0,29 & 1,25 & 0,36 & 0,08 & \\
\hline 4 & Aphelinidae & 0 & 0,00 & 6 & 8,22 & 8,22 & 0,00 & 0,00 & 0,00 & 0,00 & \\
\hline 5 & Phoridae & 0 & 0,00 & 8 & 10,96 & 10,96 & 0,00 & 0,00 & 0,00 & 0,00 & \\
\hline 6 & Tetranychidae & 6 & 28,57 & 10 & 13,70 & 42,27 & 0,29 & 1,25 & 0,36 & 0,08 & \\
\hline 7 & Tipulidae & 0 & 0,00 & 3 & 4,11 & 4,11 & 0,00 & 0,00 & 0,00 & 0,00 & \\
\hline 8 & Tephritidae & 0 & 0,00 & 1 & 1,37 & 1,37 & 0,00 & 0,00 & 0,00 & 0,00 & \\
\hline 9 & Trichogrammatidae & 3 & 14,29 & 6 & 8,22 & 22,50 & 0,14 & 1,95 & 0,28 & 0,02 & \\
\hline 10 & Thripidae & 0 & 0,00 & 5 & 6,85 & 6,85 & 0,00 & 0,00 & 0,00 & 0,00 & \\
\hline 11 & Pompilidae & 0 & 0,00 & 3 & 4,11 & 4,11 & 0,00 & 0,00 & 0,00 & 0,00 & \\
\hline 12 & Diaspididae & 5 & 23,81 & 10 & 13,70 & 37,51 & 0,24 & 1,44 & 0,34 & 0,06 & \\
\hline & Total & 21 & 100,00 & 73 & 100,00 & 200,00 & 1,00 & 8,93 & 1,48 & 0,24 & 0,60 \\
\hline
\end{tabular}

Composition Community of apple plant bugs caught trap of B2 colour (green colour 1.5m height)

\begin{tabular}{c|c|c|c|c|c|c|c|r|r|r|r|} 
No & Family & $\mathrm{D}$ & $\mathrm{DR}$ & $\mathrm{F}$ & $\mathrm{FR}$ & $\mathrm{V}$ & $\mathrm{pi}$ & $\mathrm{In}(\mathrm{pi})$ & $\mathrm{H}^{\prime}$ & $\mathrm{C}$ & $\mathrm{E}$ \\
\hline 1 & Cecidomyidae & 8 & 25,00 & 9 & 12,33 & 37,33 & 0,25 & 1,39 & 0,35 & 0,06 & \\
\hline 2 & Drosophilidae & 0 & 0,00 & 2 & 2,74 & 2,74 & 0,00 & 0,00 & 0,00 & 0,00 & \\
\hline 3 & Braconidae & 3 & 9,38 & 10 & 13,70 & 23,07 & 0,09 & 2,37 & 0,22 & 0,01 & \\
\hline 4 & Aphelinidae & 2 & 6,25 & 6 & 8,22 & 14,47 & 0,06 & 2,77 & 0,17 & 0,00 & \\
\hline 5 & Phoridae & 2 & 6,25 & 8 & 10,96 & 17,21 & 0,06 & 2,77 & 0,17 & 0,00 & \\
\hline 6 & Tetranychidae & 9 & 28,13 & 10 & 13,70 & 41,82 & 0,28 & 1,27 & 0,36 & 0,08 & \\
\hline 7 & Tipulidae & 0 & 0,00 & 3 & 4,11 & 4,11 & 0,00 & 0,00 & 0,00 & 0,00 & \\
\hline 8 & Tephritidae & 0 & 0,00 & 1 & 1,37 & 1,37 & 0,00 & 0,00 & 0,00 & 0,00 & \\
\hline 9 & Trichogrammatidae & 0 & 0,00 & 6 & 8,22 & 8,22 & 0,00 & 0,00 & 0,00 & 0,00 & \\
\hline 10 & Thripidae & 2 & 6,25 & 5 & 6,85 & 13,10 & 0,06 & 2,77 & 0,17 & 0,00 & \\
\hline 11 & Pompilidae & 0 & 0,00 & 3 & 4,11 & 4,11 & 0,00 & 0,00 & 0,00 & 0,00 & \\
\hline 12 & Diaspididae & 6 & 18,75 & 10 & 13,70 & 32,45 & 0,19 & 1,67 & 0,31 & 0,04 & \\
\hline & Total & 32 & 100,00 & 73 & 100,00 & 200,00 & 1,00 & 15,01 & 1,76 & 0,20 & 0,71 \\
\hline
\end{tabular}

Composition Community of apple plant bugs caught trap of B3 colour (blue colour $1 \mathrm{~m}$ height)

\begin{tabular}{c|c|c|c|c|c|c|c|r|r|r|r|} 
No & Family & $\mathrm{D}$ & $\mathrm{DR}$ & $\mathrm{F}$ & $\mathrm{FR}$ & $\mathrm{V}$ & $\mathrm{pi}$ & $\mathrm{In}(\mathrm{pi})$ & \multicolumn{1}{|c|}{$\mathrm{H}^{\prime}$} & $\mathrm{C}$ & $\mathrm{E}$ \\
\hline 1 & Cecidomyiidae & 0 & 0,00 & 9 & 12,33 & 12,33 & 0,00 & 0,00 & 0,00 & 0,00 & \\
\hline 2 & Drosophilidae & 0 & 0,00 & 2 & 2,74 & 2,74 & 0,00 & 0,00 & 0,00 & 0,00 & \\
\hline 3 & Braconidae & 4 & 14,29 & 10 & 13,70 & 27,98 & 0,14 & 1,95 & 0,28 & 0,02 & \\
\hline 4 & Aphelinidae & 3 & 10,71 & 6 & 8,22 & 18,93 & 0,11 & 2,23 & 0,24 & 0,01 & \\
\hline 5 & Phoridae & 6 & 21,43 & 8 & 10,96 & 32,39 & 0,21 & 1,54 & 0,33 & 0,05 & \\
\hline 6 & Tetranychidae & 6 & 21,43 & 10 & 13,70 & 35,13 & 0,21 & 1,54 & 0,33 & 0,05 & \\
\hline 7 & Tipulidae & 1 & 3,57 & 3 & 4,11 & 7,68 & 0,04 & 0,00 & 0,00 & 0,00 & \\
\hline 8 & Tephritidae & 0 & 0,00 & 1 & 1,37 & 1,37 & 0,00 & 0,00 & 0,00 & 0,00 & \\
\hline 9 & Trichogrammatidae & 1 & 3,57 & 6 & 8,22 & 11,79 & 0,04 & 3,33 & 0,12 & 0,00 & \\
\hline 10 & Thripidae & 3 & 10,71 & 5 & 6,85 & 17,56 & 0,11 & 2,23 & 0,24 & 0,01 & \\
\hline 11 & Pompilidae & 0 & 0,00 & 3 & 4,11 & 4,11 & 0,00 & 0,00 & 0,00 & 0,00 & \\
\hline 12 & Diaspididae & 4 & 14,29 & 10 & 13,70 & 27,98 & 0,14 & 1,95 & 0,28 & 0,02 & \\
\hline & Total & 28 & 100,00 & 73 & 100,00 & 200,00 & 1,00 & 14,77 & 1,81 & 0,16 & 0,73 \\
\hline
\end{tabular}

Composition Community of an apple plant bug caught trap B4 colour (blue colour 1.5m height) 
The Influence of Colour Trap to The Community Structure on Apple Plant (Tito et al.)

\begin{tabular}{c|c|c|c|c|c|c|c|r|r|r|r|} 
No & Family & $\mathrm{D}$ & $\mathrm{DR}$ & $\mathrm{F}$ & $\mathrm{FR}$ & $\mathrm{V}$ & $\mathrm{pi}$ & $\mathrm{In}(\mathrm{pi})$ & $\mathrm{H}^{\prime}$ & $\mathrm{C}$ & $\mathrm{E}$ \\
\hline 1 & Cecidomyidae & 1 & 4,55 & 9 & 12,33 & 16,87 & 0,05 & 3,09 & 0,14 & 0,00 & \\
\hline 2 & Drosophilidae & 1 & 4,55 & 2 & 2,74 & 7,29 & 0,05 & 3,09 & 0,14 & 0,00 & \\
\hline 3 & Braconidae & 8 & 36,36 & 10 & 13,70 & 50,06 & 0,36 & 1,01 & 0,37 & 0,13 & \\
\hline 4 & Aphelinidae & 0 & 0,00 & 6 & 8,22 & 8,22 & 0,00 & 0,00 & 0,00 & 0,00 & \\
\hline 5 & Phoridae & 0 & 0,00 & 8 & 10,96 & 10,96 & 0,00 & 0,00 & 0,00 & 0,00 & \\
\hline 6 & Tetranychidae & 7 & 31,82 & 10 & 13,70 & 45,52 & 0,32 & 1,15 & 0,36 & 0,10 & \\
\hline 7 & Tipulidae & 0 & 0,00 & 3 & 4,11 & 4,11 & 0,00 & 0,00 & 0,00 & 0,00 & \\
\hline 8 & Tephritidae & 0 & 0,00 & 1 & 1,37 & 1,37 & 0,00 & 0,00 & 0,00 & 0,00 & \\
\hline 9 & Trichogrammatidae & 0 & 0,00 & 6 & 8,22 & 8,22 & 0,00 & 0,00 & 0,00 & 0,00 & \\
\hline 10 & Thripidae & 0 & 0,00 & 5 & 6,85 & 6,85 & 0,00 & 0,00 & 0,00 & 0,00 & \\
\hline 11 & Pompilidae & 0 & 0,00 & 3 & 4,11 & 4,11 & 0,00 & 0,00 & 0,00 & 0,00 & \\
\hline 12 & Diaspididae & 5 & 22,73 & 10 & 13,70 & 36,43 & 0,23 & 1,48 & 0,34 & 0,05 & \\
\hline & Total & 22 & 100,00 & 73 & 100,00 & 200,00 & 1,00 & 9,82 & 1,35 & 0,29 & 0,54 \\
\hline
\end{tabular}

Composition Community of apple plant bugs caught trap of B5 colour (yellow colour 1m height)

\begin{tabular}{c|c|c|c|c|c|c|c|c|r|r|r|} 
No & Family & D & DR & F & FR & V & pi & In(pi) & $\mathrm{H}^{\prime}$ & C & $E$ \\
\hline 1 & Cecidomyidae & 8 & 32,00 & 9 & 12,33 & 44,33 & 0,32 & 1,14 & 0,36 & 0,10 & \\
\hline 2 & Drosophilidae & 0 & 0,00 & 2 & 2,74 & 2,74 & 0,00 & 0,00 & 0,00 & 0,00 & \\
\hline 3 & Braconidae & 8 & 32,00 & 10 & 13,70 & 45,70 & 0,32 & 1,14 & 0,36 & 0,10 & \\
\hline 4 & Aphelinidae & 0 & 0,00 & 6 & 8,22 & 8,22 & 0,00 & 0,00 & 0,00 & 0,00 & \\
\hline 5 & Phoridae & 1 & 4,00 & 8 & 10,96 & 14,96 & 0,04 & 3,22 & 0,13 & 0,00 & \\
\hline 6 & Tetranychidae & 4 & 16,00 & 10 & 13,70 & 29,70 & 0,16 & 1,83 & 0,29 & 0,03 & \\
\hline 7 & Tipulidae & 0 & 0,00 & 3 & 4,11 & 4,11 & 0,00 & 0,00 & 0,00 & 0,00 & \\
\hline 8 & Tephritidae & 0 & 0,00 & 1 & 1,37 & 1,37 & 0,00 & 0,00 & 0,00 & 0,00 & \\
\hline 9 & Trichogrammatidae & 0 & 0,00 & 6 & 8,22 & 8,22 & 0,00 & 0,00 & 0,00 & 0,00 & \\
\hline 10 & Thripidae & 0 & 0,00 & 5 & 6,85 & 6,85 & 0,00 & 0,00 & 0,00 & 0,00 & \\
\hline 11 & Pompilidae & 1 & 4,00 & 3 & 4,11 & 8,11 & 0,04 & 3,22 & 0,13 & 0,00 & \\
\hline 12 & Diaspididae & 3 & 12,00 & 10 & 13,70 & 25,70 & 0,12 & 2,12 & 0,25 & 0,01 & \\
\hline & Total & 25 & 100,00 & 73 & 100,00 & 200,00 & 1,00 & 12,67 & 1,53 & 0,25 & 0,62 \\
\hline
\end{tabular}

Composition Community of apple plant bugs caught trap of B6 colour (yellow colour 1.5m height)

\begin{tabular}{c|c|c|c|c|c|c|c|r|r|r|r|} 
No & Family & D & DR & F & FR & V & pi & In(pi) & $\mathrm{H}^{\prime}$ & C & E \\
\hline 1 & Cecidomyidae & 1 & 2,56 & 9 & 12,33 & 14,89 & 0,03 & 3,66 & 0,09 & 0,00 & \\
\hline 2 & Drosophilidae & 0 & 0,00 & 2 & 2,74 & 2,74 & 0,00 & 0,00 & 0,00 & 0,00 & \\
\hline 3 & Braconidae & 5 & 12,82 & 10 & 13,70 & 26,52 & 0,13 & 2,05 & 0,26 & 0,02 & \\
\hline 4 & Aphelinidae & 2 & 5,13 & 6 & 8,22 & 13,35 & 0,05 & 2,97 & 0,15 & 0,00 & \\
\hline 5 & Phoridae & 3 & 7,69 & 8 & 10,96 & 18,65 & 0,08 & 2,56 & 0,20 & 0,01 & \\
\hline 6 & Tetranychidae & 21 & 53,85 & 10 & 13,70 & 67,54 & 0,54 & 0,62 & 0,33 & 0,29 & \\
\hline 7 & Tipulidae & 0 & 0,00 & 3 & 4,11 & 4,11 & 0,00 & 0,00 & 0,00 & 0,00 & \\
\hline 8 & Tephritidae & 0 & 0,00 & 1 & 1,37 & 1,37 & 0,00 & 0,00 & 0,00 & 0,00 & \\
\hline 9 & Trichogrammatidae & 0 & 0,00 & 6 & 8,22 & 8,22 & 0,00 & 0,00 & 0,00 & 0,00 & \\
\hline 10 & Thripidae & 3 & 7,69 & 5 & 6,85 & 14,54 & 0,08 & 2,56 & 0,20 & 0,01 & \\
\hline 11 & Pompilidae & 0 & 0,00 & 3 & 4,11 & 4,11 & 0,00 & 0,00 & 0,00 & 0,00 & \\
\hline 12 & Diaspididae & 4 & 10,26 & 10 & 13,70 & 23,96 & 0,10 & 2,28 & 0,23 & 0,01 & \\
\hline & Total & 39 & 100,00 & 73 & 100,00 & 200,00 & 1,00 & 16,71 & 1,47 & 0,33 & 0,59 \\
\hline
\end{tabular}


Composition Community of apple plant bugs caught trap of B7 colour (white colour 1m height)

\begin{tabular}{c|c|c|c|c|c|c|c|r|r|r|r|} 
No & Family & D & DR & F & FR & VI & pi & In(pi) & $H^{\prime}$ & C & E \\
\hline 1 & Cecidomyidae & 3 & 6,12 & 9 & 12,33 & 18,45 & 0,06 & 2,79 & 0,17 & 0,00 & \\
\hline 2 & Drosophilidae & 0 & 0,00 & 2 & 2,74 & 2,74 & 0,00 & 0,00 & 0,00 & 0,00 & \\
\hline 3 & Braconidae & 1 & 2,04 & 10 & 13,70 & 15,74 & 0,02 & 3,89 & 0,08 & 0,00 & \\
\hline 4 & Aphelinidae & 2 & 4,08 & 6 & 8,22 & 12,30 & 0,04 & 3,20 & 0,13 & 0,00 & \\
\hline 5 & Phoridae & 1 & 2,04 & 8 & 10,96 & 13,00 & 0,02 & 3,89 & 0,08 & 0,00 & \\
\hline 6 & Tetranychidae & 16 & 32,65 & 10 & 13,70 & 46,35 & 0,33 & 1,12 & 0,37 & 0,11 & \\
\hline 7 & Tipulidae & 1 & 2,04 & 3 & 4,11 & 6,15 & 0,02 & 3,89 & 0,08 & 0,00 & \\
\hline 8 & Tephritidae & 0 & 0,00 & 1 & 1,37 & 1,37 & 0,00 & 0,00 & 0,00 & 0,00 & \\
\hline 9 & Trichogrammatidae & 1 & 2,04 & 6 & 8,22 & 10,26 & 0,02 & 3,89 & 0,08 & 0,00 & \\
\hline 10 & Thripidae & 3 & 6,12 & 5 & 6,85 & 12,97 & 0,06 & 2,79 & 0,17 & 0,00 & \\
\hline 11 & Pompilidae & 0 & 0,00 & 3 & 4,11 & 4,11 & 0,00 & 0,00 & 0,00 & 0,00 & \\
\hline 12 & Diaspididae & 21 & 42,86 & 10 & 13,70 & 56,56 & 0,43 & 0,85 & 0,36 & 0,18 & \\
\hline & Total & 49 & 100,00 & 73 & 100,00 & 200,00 & 1,00 & 26,32 & 1,52 & 0,30 & 0,61 \\
\hline
\end{tabular}

Composition Community of apple plant bugs caught trap of B8 colour (white colour 1.5m height)

\begin{tabular}{c|c|c|c|c|c|c|c|r|r|r|r|} 
No & Family & D & DR & F & FR & V & pi & In(pi) & $H^{\prime}$ & C & E \\
\hline 1 & Cecidomyiidae & 3 & 7,69 & 9 & 12,33 & 20,02 & 0,08 & 2,56 & 0,20 & 0,01 & \\
\hline 2 & Drosophilidae & 0 & 0,00 & 2 & 2,74 & 2,74 & 0,00 & 0,00 & 0,00 & 0,00 & \\
\hline 3 & Braconidae & 5 & 12,82 & 10 & 13,70 & 26,52 & 0,13 & 2,05 & 0,26 & 0,02 & \\
\hline 4 & Aphelinidae & 3 & 7,69 & 6 & 8,22 & 15,91 & 0,08 & 2,56 & 0,20 & 0,01 & \\
\hline 5 & Phoridae & 2 & 5,13 & 8 & 10,96 & 16,09 & 0,05 & 2,97 & 0,15 & 0,00 & \\
\hline 6 & Tetranychidae & 11 & 28,21 & 10 & 13,70 & 41,90 & 0,28 & 1,27 & 0,36 & 0,08 & \\
\hline 7 & Tipulidae & 0 & 0,00 & 3 & 4,11 & 4,11 & 0,00 & 0,00 & 0,00 & 0,00 & \\
\hline 8 & Tephritidae & 0 & 0,00 & 1 & 1,37 & 1,37 & 0,00 & 0,00 & 0,00 & 0,00 & \\
\hline 9 & Trichogrammatidae & 2 & 5,13 & 6 & 8,22 & 13,35 & 0,05 & 2,97 & 0,15 & 0,00 & \\
\hline 10 & Thripidae & 5 & 12,82 & 5 & 6,85 & 19,67 & 0,13 & 2,05 & 0,26 & 0,02 & \\
\hline 11 & Pompilidae & 0 & 0,00 & 3 & 4,11 & 4,11 & 0,00 & 0,00 & 0,00 & 0,00 & \\
\hline 12 & Diaspididae & 8 & 20,51 & 10 & 13,70 & 34,21 & 0,21 & 1,58 & 0,32 & 0,04 & \\
\hline & Total & 39 & 100,00 & 73 & 100,00 & 200,00 & 1,00 & 18,03 & 1,91 & 0,17 & 0,77 \\
\hline
\end{tabular}

\section{Composition Community of apple plant bugs caught trap of B9 colour (clear colour 1m height)}

\begin{tabular}{c|c|c|c|c|c|c|c|r|r|r|r|} 
No & Family & $\mathrm{D}$ & $\mathrm{DR}$ & $\mathrm{F}$ & $\mathrm{FR}$ & $\mathrm{V}$ & $\mathrm{pi}$ & $\mathrm{In}(\mathrm{pi})$ & $\mathrm{H}^{\prime}$ & $\mathrm{C}$ & $\mathrm{E}$ \\
\hline 1 & Cecidomyiidae & 3 & 10,00 & 9 & 12,33 & 22,33 & 0,10 & 2,30 & 0,23 & 0,01 & \\
\hline 2 & Drosophilidae & 4 & 13,33 & 2 & 2,74 & 16,07 & 0,13 & 2,01 & 0,27 & 0,02 & \\
\hline 3 & Braconidae & 7 & 23,33 & 10 & 13,70 & 37,03 & 0,23 & 1,46 & 0,34 & 0,05 & \\
\hline 4 & Aphelinidae & 1 & 3,33 & 6 & 8,22 & 11,55 & 0,03 & 3,40 & 0,11 & 0,00 & \\
\hline 5 & Phoridae & 2 & 6,67 & 8 & 10,96 & 17,63 & 0,07 & 2,71 & 0,18 & 0,00 & \\
\hline 6 & Tetranychidae & 7 & 23,33 & 10 & 13,70 & 37,03 & 0,23 & 1,46 & 0,34 & 0,05 & \\
\hline 7 & Tipulidae & 1 & 3,33 & 3 & 4,11 & 7,44 & 0,03 & 3,40 & 0,11 & 0,00 & \\
\hline 8 & Tephritidae & 1 & 3,33 & 1 & 1,37 & 4,70 & 0,03 & 3,40 & 0,11 & 0,00 & \\
\hline 9 & Trichogrammatidae & 1 & 3,33 & 6 & 8,22 & 11,55 & 0,03 & 3,40 & 0,11 & 0,00 & \\
\hline 10 & Thripidae & 0 & 0,00 & 5 & 6,85 & 6,85 & 0,00 & 0,00 & 0,00 & 0,00 & \\
\hline 11 & Pompilidae & 1 & 3,33 & 3 & 4,11 & 7,44 & 0,03 & 3,40 & 0,11 & 0,00 & \\
\hline 12 & Diaspididae & 2 & 6,67 & 10 & 13,70 & 20,37 & 0,07 & 2,71 & 0,18 & 0,00 & \\
\hline & Total & 30 & 100,00 & 73 & 100,00 & 200,00 & 1,00 & 29,65 & 2,11 & 0,15 & 0,85 \\
\hline
\end{tabular}


The Influence of Colour Trap to The Community Structure on Apple Plant (Tito et al.)

Composition Community of an apple plant bug caught trap B10 colour (clear colour height 1.5m)

\begin{tabular}{c|c|c|c|c|c|c|c|r|r|r|r|} 
No & Family & $\mathrm{D}$ & $\mathrm{DR}$ & $\mathrm{F}$ & $\mathrm{FR}$ & $\mathrm{V}$ & $\mathrm{pi}$ & $\mathrm{In}(\mathrm{pi})$ & $\mathrm{H}^{\prime}$ & $\mathrm{C}$ & $\mathrm{E}$ \\
\hline 1 & Cecidomyiidae & 13 & 26,53 & 9 & 12,33 & 38,86 & 0,27 & 1,33 & 0,35 & 0,07 & \\
\hline 2 & Drosophilidae & 0 & 0,00 & 2 & 2,74 & 2,74 & 0,00 & 0,00 & 0,00 & 0,00 & \\
\hline 3 & Braconidae & 5 & 10,20 & 10 & 13,70 & 23,90 & 0,10 & 2,28 & 0,23 & 0,01 & \\
\hline 4 & Aphelinidae & 0 & 0,00 & 6 & 8,22 & 8,22 & 0,00 & 0,00 & 0,00 & 0,00 & \\
\hline 5 & Phoridae & 1 & 2,04 & 8 & 10,96 & 13,00 & 0,02 & 3,89 & 0,08 & 0,00 & \\
\hline 6 & Tetranychidae & 16 & 32,65 & 10 & 13,70 & 46,35 & 0,33 & 1,12 & 0,37 & 0,11 & \\
\hline 7 & Tipulidae & 0 & 0,00 & 3 & 4,11 & 4,11 & 0,00 & 0,00 & 0,00 & 0,00 & \\
\hline 8 & Tephritidae & 0 & 0,00 & 1 & 1,37 & 1,37 & 0,00 & 0,00 & 0,00 & 0,00 & \\
\hline 9 & Trichogrammatidae & 2 & 4,08 & 6 & 8,22 & 12,30 & 0,04 & 3,20 & 0,13 & 0,00 & \\
\hline 10 & Thripidae & 0 & 0,00 & 5 & 6,85 & 6,85 & 0,00 & 0,00 & 0,00 & 0,00 & \\
\hline 11 & Pompilidae & 1 & 2,04 & 3 & 4,11 & 6,15 & 0,02 & 3,89 & 0,08 & 0,00 & \\
\hline 12 & Diaspididae & 11 & 22,45 & 10 & 13,70 & 36,15 & 0,22 & 1,49 & 0,34 & 0,05 & \\
\hline & Total & 49 & 100,00 & 73 & 100,00 & 200,00 & 1,00 & 17,20 & 1,58 & 0,24 & 0,63 \\
\hline
\end{tabular}

